\title{
Adherence to Immunosuppressive Therapy in Kidney Transplant Recipients: Integrative Literature Review
}

\author{
A Adesão à Terapêutica Imunossupressora na Pessoa Transplantada Renal: \\ Revisão Integrativa da Literatura \\ La Adhesión a la Terapia Inmunosupresora en el Paciente con Trasplante Renal: \\ Revisión Integradora de la Literatura \\ Pedro Ricardo Coelho Gonçalves*; Anaísa Ferreira Reveles**; Helena Isabel Fernandes Martins***; \\ Inês Lourenço Rodrigues****; Susana Margarida Miranda Rodrigues*****
}

\begin{abstract}
Background: Kidney transplantation requires strict adherence to the immunosuppressive therapy. Non-adherence is a common multifactorial problem among kidney transplant recipients.

Objectives: To identify the factors influencing the adherence to the immunosuppressive therapy among kidney transplant recipients. Methodology: This is an integrative literature review. After establishing the inclusion and exclusion criteria and analyzing the studies, we selected 10 primary studies that answered the research question. These articles were published between 2009 and 2014 and were obtained through the online platforms EBSCOhost and Online Knowledge Library (B-on).

Results: Adherence to immunosuppressive therapy is mainly influenced by socio-economic and cultural factors (age, gender, education, occupational situation), patient-related factors (forgetfulness, daily routines), condition-related factors (time since transplant, depression), and therapy-related factors (complexity of the therapeutic regimen).

Conclusion: Knowing the factors that influence adherence allow planning (both educational and behavioral) nursing interventions aimed at promoting the adherence to immunosuppressive therapy, thus improving the patients' health.
\end{abstract}

Keywords: medication adherence; risk factors; kidney transplantation

\section{Resumo}

Enquadramento: $\mathrm{O}$ transplante renal exige da pessoa uma estrita adesão à terapêutica imunossupressora. A não-adesão é um problema multifatorial e comum entre as pessoas transplantadas renais.

Objetivos: Identificar os fatores que influenciam a adesão à terapêutica imunossupressora na pessoa transplantada renal.

Metodologia: Trata-se de uma revisão integrativa da literatura. Após estabelecimento dos critérios de inclusão e exclusão e análise dos investigadores foram selecionados 10 artigos primários, publicados entre 2009-2014 e pesquisados nas plataformas eletrónicas EBSCOhost e Biblioteca do Conhecimento Online que deram resposta à questão de revisão.

Resultados: Os principais fatores que contribuem para a adesão à terapêutica imunossupressora são os socioeconómicos e culturais (idade, sexo, escolaridade, situação profissional), relacionados com a pessoa (esquecimento, rotinas diárias), com a doença (tempo de transplante, depressão) e com o tratamento (complexidade do regime terapêutico).

Conclusão: O facto de se conhecerem os fatores que influenciam a adesão permite delinear intervenções de enfermagem (educacionais e comportamentais) que promovam a adesão à terapêutica imunossupressora, com ganhos em saúde para a pessoa.

Palavras-chave: adesão à medicação; fatores de risco; transplante de rim

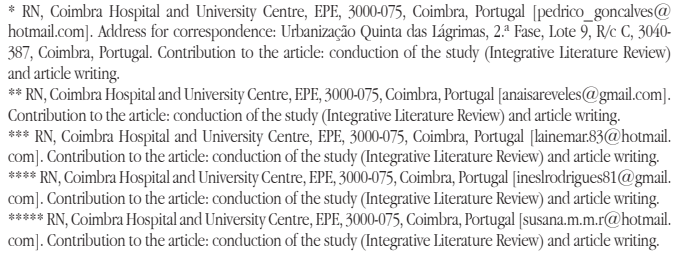

\section{Resumen}

Marco contextual: El trasplante de riñón requiere que la persona siga rigurosamente la terapia inmunosupresora. La falta de adhesión a esta terapia es un problema multifactorial y común en las personas con trasplante renal.

Objetivos: Identificar los factores que influyen en la adhesión a la terapia inmunosupresora en el paciente con trasplante de riñón. Metodología: Se trata de una revisión integradora de la literatura. Después de establecer los criterios de inclusión y exclusión y análisis de los investigadores, se seleccionaron 10 artículos primarios, publicados entre 2009 y 2014, y buscados en las plataformas electrónicas EBSCOhost y Biblioteca do Conhecimento Online que respondieron a la cuestión de la revisión.

Resultados: Los principales factores que contribuyen a la adhesión a la terapia inmunosupresora son los socioeconómicos y culturales (edad, sexo, escolaridad, situación profesional), los relacionados con la persona (olvido, rutinas diarias), con la enfermedad (tiempo de trasplante, depresión) y con el tratamiento (complejidad del régimen terapéutico).

Conclusión: El hecho de conocer los factores que influyen en la adhesión permite definir las intervenciones de enfermería (educativas y de comportamiento) que promueven la adhesión a la terapia inmunosupresora, con beneficios para la salud del paciente.

Palabras clave: cumplimiento de la medicación; factores de riesgo; trasplante de riñón

Received for publication: 11.09.14

Accepted for publication: 06.12 .15 


\section{Introduction}

Kidney transplantation is considered to be the treatment of choice for patients with End-Stage Renal Disease and, in comparison to the general healthy population of the same age group, allows obtaining the best outcomes in terms of survival, as well as the best indicators of health-related quality of life (Ministério da Saúde. Direção-Geral da Saúde, 2012). Transplant recipients undergo a health/ illness transition process in which the adherence to the therapeutic regimen, and in particular to the immunosuppressive therapy, play a significant role in their health and well-being. The immunosuppressive therapy aims to prevent acute and chronic rejection. According to the International Council of Nurses (ICN; 2011), adherence is a

self-initiated action to promote wellness, recovery and rehabilitation, following directions without deviation, devoted to a set of actions or behaviours. Compliant with treatment regimen, taking medicine as instructed, behaviour change for the better, signs of healing, collection of medicine on due date, internalisation of the value of health care behaviour and obeying instructions regarding treatment. (p. 38)

Adherence requires the patient's agreement to the health professionals' recommendations, and patients should be active partners in their own care. According to the World Health Organization (WHO; 2003), good communication between patients and health professionals is a must for an effective clinical practice with health gains.

In 2008, the Consensus Conference, which brought together several North-American organizations to discuss immunosuppressant non-adherence in transplant recipients, defined immunosuppressant non-adherence as the "deviation from the prescribed medication regimen sufficient to influence adversely the regimen's intended effect" (Fine et al., 2009, p. 36). The poor adherence or non-adherence to treatment causes physical and psychological complications in the patients, reduces their quality of life, increases the likelihood of development of drug resistance, and wastes resources, compromising the efforts of the health system to improve the health of the population (ICN, 2009). Thus, measuring adherence is imperative in order to determine the magnitude of the problem and to identify the contributing factors.
Evidence shows that non-adherence is a common multifactorial problem among kidney transplant recipients, who have substantially higher rates than other recipients of solid organs (Chisholm-Burns et al., 2012; Griva, Davenport, Harrison, \& Newman, 2012; Weng et al., 2013). Approximately 35\% of kidney graft losses are related to non-adherence to immunosuppressive therapy, being that the probability of graft failure is seven times higher in non-adherent patients than in adherent patients. In addition, life expectancy is four times lower in non-adherent patients than in adherent patients (Chisholm-Burns, Spivey, \& Wilks, 2010).

In light of the above, the ICN proposes a combination of educational and behavioral strategies to promote adherence. A multidisciplinary approach is mandatory, in which the family, community, and patients' organizations are key partners in promoting adherence (ICN, 2009).

This integrative literature review aims at identifying the factors influencing adherence to immunosuppressive therapy. After the identification of these factors, we also intend to identify nursing interventions capable of improving adherence among kidney transplant recipients. Our objective is to answer the following research question: Which factors influence the adherence to immunosuppressive therapy among kidney transplant recipients?

\section{Methodological Procedures of the Integrative Review}

The integrative literature review was performed in six steps, as recommended by Botelho, Cunha, and Macedo (2011): identification of the theme and selection of the research question; establishment of the inclusion and exclusion criteria; identification of the pre-selected and selected studies; classification of the selected studies; analysis and interpretation of results; and, finally, presentation of the review/ synthesis of knowledge.

The review question was defined on the basis of the $\mathrm{PI}(\mathrm{C}) \mathrm{O}$ method. The participants $(\mathrm{P})$ are the kidney transplant recipients. The independent variables (I) are the influencing factors. The outcome $(0)$ is the adherence to the immunosuppressive therapy.

The literature search was performed in the last week of March, 2014 on the online platforms EBSCOhost, Online Knowledge Library (B-on), and in the Open 
Access Scientific Repository of Portugal (RCAAP). In the EBSCOhost platform, the search was performed in the following online databases: CINAHL Plus with Full Text, MEDLINE with Full Text, Nursing and Allied Health Collection: Basic, Cochrane Central Register of Controlled Trials, Cochrane Database of Systematic Reviews, Cochrane Methodology Register, and MedicLatina.

Table 1

\section{Inclusion and exclusion criteria}

The descriptors used in the search were "adherence" and "kidney transplantation", linked with the Boolean operator AND. In RCAAP, we used the same descriptors, but in Portuguese (adesão e transplante renal).

Table 1 describes the inclusion and exclusion criteria for article selection.

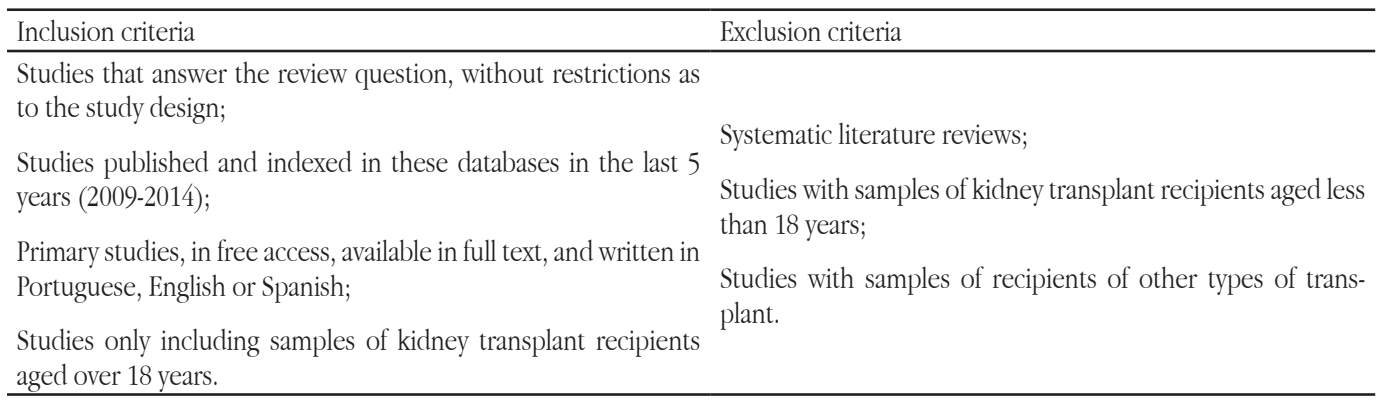

In order to systemize the information on the articles, we designed an observation grid with the following topics of analysis.

\section{Results and Interpretation}

In a first phase, two researchers reviewed the titles of all articles. In a second phase, three researchers read the abstracts. In a third phase, two or more researchers analyzed the full text of all potentially relevant articles to be included in this integrative literature review. Figure 1 shows the data reduction process of the integrative literature review.

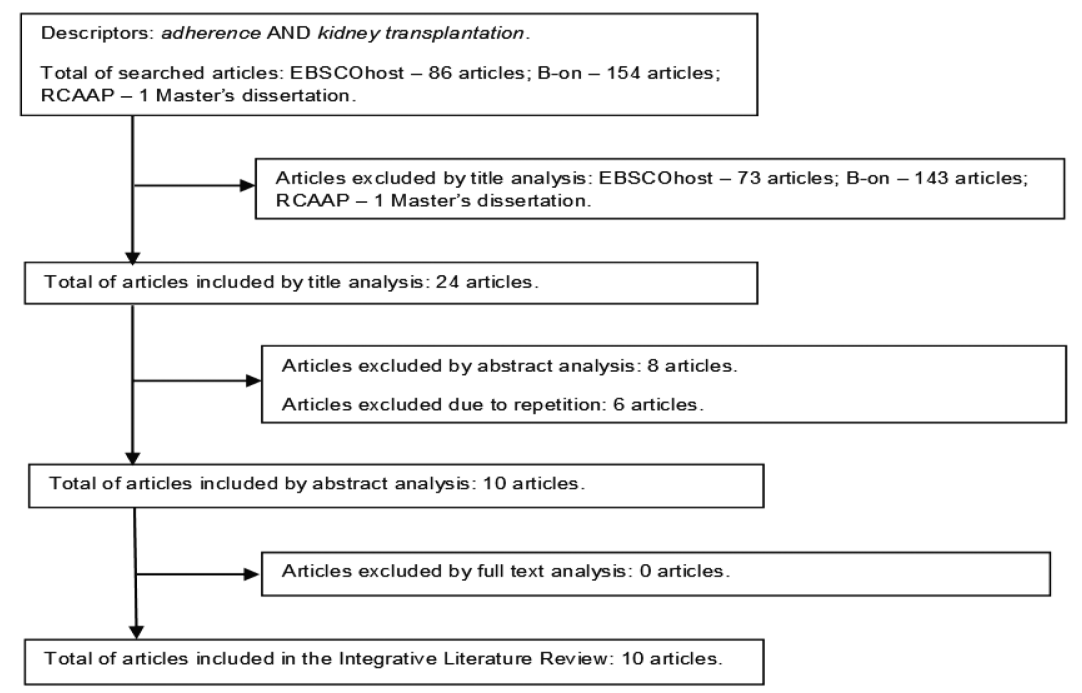

Figure 1. Data reduction process of the Integrative Literature Review. 
The 10 selected articles were independently analyzed in full by two or more researchers until a consensus was reached (in terms of methodology, content, and relevance of results) for the integration of the studies in this integrative literature review. Table 2 shows the selected studies.

Table 2

Selected studies

\begin{tabular}{|c|c|c|}
\hline Study & Article & Type of study \\
\hline S1 & $\begin{array}{l}\text { Maissiat, G. S., Marin, S. M., \& Fuzinatto, C. R. D. (2013). Adherence to im- } \\
\text { munosuppressive treatment in post-renal transplant patients: a descriptive- } \\
\text { exploratory study. Online Brazilian Journal of Nursing, 12(2), 269-282. }\end{array}$ & $\begin{array}{l}\text { Quantitative, cross-sectional, } \\
\text { descriptive-exploratory }\end{array}$ \\
\hline S2 & $\begin{array}{l}\text { Chisholm-Burns, M., Pinsky, B., Parker, G., Johnson, P., Arcona, S., Buzinec, P., } \\
\text { \& Cooper, M. (2012). Factors related to immunosuppressant medication ad- } \\
\text { herence in renal transplant recipients. Clinical Transplantation, 26, 706-713. }\end{array}$ & $\begin{array}{l}\text { Quantitative, cross-sectional, } \\
\text { descriptive-exploratory }\end{array}$ \\
\hline S3 & $\begin{array}{l}\text { Griva, K., Davenport, A., Harrison, M., \& Newman, S. P. (2012). Non-adher- } \\
\text { ence to Immunosuppressive Medications in Kidney Transplantation: Intent Vs. } \\
\text { Forgetfulness and Clinical Markers of Medication Intake. Annals of Bebavioral } \\
\text { Medicine, } 44,85-93 \text {. }\end{array}$ & $\begin{array}{l}\text { Quantitative, cross-sectional, } \\
\text { descriptive-correlational }\end{array}$ \\
\hline S4 & $\begin{array}{l}\text { Chisholm-Burns, M. A., Spivey, C. A., \& Wilks, S. E. (2010). Social support and } \\
\text { immunosuppressant therapy adherence among adult renal transplant recipi- } \\
\text { ents. Clinical Transplantation, } 24,312-320 \text {. }\end{array}$ & $\begin{array}{l}\text { Quantitative, cross-sectional, } \\
\text { descriptive-exploratory }\end{array}$ \\
\hline S5 & $\begin{array}{l}\text { Schmid-Mohler, G., Thut, M. P., Wüthrich, R. P., Denhaerynck, K, \& Geest, S. } \\
\text { (2010). Non-adherence to immunosuppressive medication in renal transplant } \\
\text { recipients within the scope of the integrative model of behavioral prediction: } \\
\text { a cross-sectional study. Clinical Transplantation, 24, 213-222. }\end{array}$ & $\begin{array}{l}\text { Quantitative, cross-sectional, } \\
\text { descriptive-exploratory }\end{array}$ \\
\hline S6 & $\begin{array}{l}\text { Obi, Y., Ichimaru, N., Kato, T., Kaimori, J., Okumi, M., Yazawa, K., \& Takahara, } \\
\text { S. (2013). A single daily dose enhances the adherence to immunosuppressive } \\
\text { treatment in kidney transplant recipients: a cross-sectional study. Clinical } \\
\text { and Experimental Nephrology, 17, 310-315. }\end{array}$ & $\begin{array}{l}\text { Quantitative, cross-sectional, } \\
\text { descriptive-exploratory }\end{array}$ \\
\hline S7 & $\begin{array}{l}\text { Massey, E. K., Tielen, M., Laging, M., Beck, D. K., Khemai, R., Gelder, T., \& } \\
\text { Weimar, W. (2013). The role of goal cognitions, illness perceptions and treat- } \\
\text { ment beliefs in self-reported adherence after kidney transplantation: A cohort } \\
\text { study. Journal of Psychosomatic Research, } 75,229-234 .\end{array}$ & $\begin{array}{l}\text { Quantitative, prospective, cor- } \\
\text { relational }\end{array}$ \\
\hline S8 & $\begin{array}{l}\text { Weng, F. L., Chandwani, S., Kurtyka, K. M., Zacker, C., Chisholm-Burns, M. A., } \\
\text { \& Demissie, K. (2013). Prevalence and correlates of medication non-adher- } \\
\text { ence among kidney transplant recipients more than } 6 \text { months post-transplant: } \\
\text { a cross-sectional study. BMC Nephrology, 14(261), 1-10. }\end{array}$ & $\begin{array}{l}\text { Quantitative, cross-sectional, } \\
\text { descriptive-correlational }\end{array}$ \\
\hline S9 & $\begin{array}{l}\text { Chisholm-Burns, M. A., Spivey, C. A., Graff Zivin, J., Lee, J. K., Sredzinski, E., \& } \\
\text { Tolley, E. A. (2013). Improving Outcomes of Renal Transplant Recipients With } \\
\text { Behavioral Adherence Contracts: A Randomized Controlled Trial. American } \\
\text { Journal of Transplantation, 13(9), 2364-2373. }\end{array}$ & $\begin{array}{l}\text { Quantitative, randomized clini- } \\
\text { cal trial }\end{array}$ \\
\hline S10 & $\begin{array}{l}\text { Russel, C. L., Ashbaugh, C., Peace, L., Cetingok, M., Hamburguer, K. Q., Ow- } \\
\text { ens, S., \& Wakefield, M. R. (2013). Time-in-a-bottle (TIAB): a longitudinal, } \\
\text { correlational study of patterns, potential predictors, and outcomes of im- } \\
\text { munosuppressive medication adherence in adult kidney transplant recipients. } \\
\text { Clinical Transplantation, 27, 580-590. }\end{array}$ & $\begin{array}{l}\text { Quantitative, } 1 \text { longitudinal, } \\
\text { descriptive-correlational }\end{array}$ \\
\hline
\end{tabular}

The articles included in the integrative literature review result from quantitative studies, with most of them being descriptive-exploratory studies. We assessed the methodological quality of the 10 selected articles by means of a modified version of a quality appraisal tool adapted by Crombie in 1996 (Steele, Bialocerkowski, \& Grimmer, 2003). This instrument is composed of 16 items, where one point is allocated if the item is reflected in the study, and zero points if the item is missing or unclear (Steele et al., 2003). Taking into account the total score, most of the articles (80\%) showed a high quality, whereas two articles (S1 and S4) showed a moderate quality.

We elaborated Table 3 in order to synthesize and easily consult the obtained data (sample/data collection tool, and main results). 
Table 3

Summary of the selected studies

\begin{tabular}{|c|c|c|}
\hline & Sample/Data collection tool & Results \\
\hline S1 & $\begin{array}{l}n=50 \\
\text { Measuring Test of Adherence to Treatments (Morisky } \\
\& \text { Green). }\end{array}$ & $\begin{array}{l}76 \% \text { of the participants were non-adherent. } \\
31 \% \text { reported that non-adherence was not intentional (forget- } \\
\text { fulness and carelessness). } \\
2 \% \text { of the non-adherent subjects reported lack of motivation } \\
\text { to continue treatment. }\end{array}$ \\
\hline S2 & $\begin{array}{l}n=512 \\
\text { - Immunosuppressant therapy adherence scale } \\
\text { (ITAS); } \\
\text { - Immunosuppressant Therapy Barrier Scale (ITBS); } \\
\text { - Beliefs about Medicines Questionnaire (BMQ); } \\
\text { - Life Satisfaction Index (LSI). }\end{array}$ & $\begin{array}{l}34.5 \% \text { of the participants were non-adherent. } \\
\text { Factors of adherence: older age ( } 46-64 \text { years). } \\
\text { Factors of non-adherence: forgetfulness, younger age (18-29 } \\
\text { years). }\end{array}$ \\
\hline S3 & $\begin{array}{l}n=218 \\
\text { - Clinical information collected from medical records; } \\
\text { - Beck Depression Inventory II; } \\
\text { - Cognitive Depression Index; } \\
\text { - Transplant Effects Questionnaire; } \\
\text { - Beliefs about Medicines Questionnaire (BMQ); } \\
\text { - Kidney Disease Quality of Life Short-Form version } \\
\text { 1.3; } \\
\text { - Medication Adherence Report Scale (MARS); } \\
\text { - Serum concentrations of immunosuppressants. }\end{array}$ & $\begin{array}{l}51.4 \% \text { of the participants admitted to be non-adherent. Of } \\
\text { these, } 62.4 \% \text { reported unintentional non-adherence, whereas } \\
\text { only } 13.8 \% \text { admitted intentional non-compliance. } \\
\text { Factors of non-adherence: forgetfulness, younger age, male } \\
\text { gender, less time on dialysis, beliefs about the need for } \\
\text { medication and concern about the viability of the graft, lower } \\
\text { education, employed, married/cohabiting, concern about drug } \\
\text { regimen, not refilling prescriptions, and depression. }\end{array}$ \\
\hline S4 & $\begin{array}{l}n=61 \\
\text { - Modified Social Support Survey (MSSS-5); } \\
\text { - Immunosuppressant Therapy Adherence Scale } \\
\text { (ITAS). }\end{array}$ & $\begin{array}{l}\text { No significant correlation was found between adherence and } \\
\text { demographic characteristics. } \\
\text { A positive association was found between social support and } \\
\text { medication adherence. }\end{array}$ \\
\hline S5 & $\begin{array}{l}n=114 \\
\text { - Information on medical files; } \\
\text { - Integrative Model of Behavioral Prediction; } \\
\text { - Basel Assessment of Adherence Scale for Immuno- } \\
\text { suppressives (BAASIS); } \\
\text { - Long-Term Medication Behavior Self-Efficacy Scale - } \\
\text { adapted version. }\end{array}$ & $\begin{array}{l}26.4 \% \text { of the participants were non-adherent and } 36.8 \% \text { were } \\
\text { partially adherent. } \\
\text { Factors of non-adherence: forgetfulness, interruption of daily } \\
\text { routine, frequency of medication intake. }\end{array}$ \\
\hline S6 & $\begin{array}{l}n=312 \\
\text { - Questionnaire. }\end{array}$ & $\begin{array}{l}\text { Factors of adherence: single daily dose of immunosuppres- } \\
\text { sant, female gender, shorter time since transplant, more pre- } \\
\text { scribed drugs, some occupations (full-time homemaker and } \\
\text { unemployment), and family member as donor. } \\
\text { Factors of non-adherence: younger age, male gender, and time } \\
\text { since transplant. Patients become non-adherent due to the } \\
\text { complexity of the treatment regimen, rather than due to the } \\
\text { number of prescribed drugs. }\end{array}$ \\
\hline S7 & $\begin{array}{l}n=113 \text { (6 weeks after renal transplant) } \\
n=106 \text { (6 months after renal transplant) } \\
\text { - Basel Assessment of Adherence to Immunosuppres- } \\
\text { sive Medications Scale (BAASISC Interview); } \\
\text { - Goal cognition items, adapted from a study by } \\
\text { Pomaki et al. (2004); } \\
\text { - Brief Illness Perceptions Questionnaire (B-IPQ); } \\
\text { - Beliefs about Medicines Questionnaire (BMQ). }\end{array}$ & $\begin{array}{l}\text { Six weeks after transplant, } 17 \% \text { of participants were non- } \\
\text { adherent, and } 6 \text { months after transplant, non-adherence } \\
\text { increased to } 27 \% \text {. } \\
\text { Factors of non-adherence: younger age, increasing perceived } \\
\text { longevity of the graft. }\end{array}$ \\
\hline
\end{tabular}




\begin{tabular}{|c|c|c|}
\hline S8 & $\begin{array}{l}n=252 \\
\text { - Immunosuppressive Therapy Adherence Scale } \\
(\text { ITAS); } \\
\text { - Immunosuppressive Therapy Barriers Scale (ITBS); } \\
\text { - Hospital Anxiety and Depression Scale (HADS); } \\
\text { - Interpersonal Support and Evaluation List-12 (ISEL- } \\
\text { 12); } \\
\text { - Perceived Stress Scale - } 4 \text { (PSS-4); } \\
\text { - Short Test of Functional Health Literacy in Adults } \\
\text { (sTOFHLA). }\end{array}$ & $\begin{array}{l}59.1 \% \text { of the participants showed excellent adherence. } \\
\text { Factors of non-adherence: depression, perceived stress, low } \\
\text { household income, and unemployment. } \\
\text { The higher the number of perceived barriers (forgetfulness, } \\
\text { changes in daily routine), the lower the adherence. }\end{array}$ \\
\hline S9 & $\begin{array}{l}n=150 \text { ( } n=76 \text { in the intervention group; } n=74 \\
\text { in the control group) } \\
\text { - Pharmacy refill records; } \\
\text { - Monthly questionnaires; } \\
\text { - 2009 Medicare Expenditure Panel Survey. }\end{array}$ & $\begin{array}{l}\text { Prerequisites to the adherence contract: patient's motivation } \\
\text { for adherence, identification of barriers and possible solutions, } \\
\text { social support (significant person), and support tools/strate- } \\
\text { gies to remember the dosing schedule, and possible conse- } \\
\text { quences of non-adherence. }\end{array}$ \\
\hline S10 & $\begin{array}{l}n=121 \\
\text { - Beck Depression Inventory (BDI); } \\
\text { - Long-Term Medication Admin-approved Self-Effica- } \\
\text { cy Scale (LTMBSES); } \\
\text { - Social Support Appraisals Index (SSAI); } \\
\text { - Medication Event Monitoring System (MEMS). }\end{array}$ & $\begin{array}{l}\text { Factors of adherence: older age, self- efficacy. } \\
\text { No association was found between medication adherence and } \\
\text { gender, ethnicity, marital status, employment, education, time } \\
\text { since transplant, depression, social support, creatinine level, } \\
\text { number of infections, acute and chronic rejections, kidney } \\
\text { loss, or death. }\end{array}$ \\
\hline
\end{tabular}

The rate of non-adherence ranged from $26.4 \%$ to $76 \%$ in the analyzed studies. Based on the analysis of the results, we decided to classify the factors that influence therapeutic adherence based on the categories proposed by the WHO (2003): social-economic and cultural factors; patient-related factors; condition-related factors; social-economic and cultural factors; patient-related factors; condition-related factors; therapy-related factors; and health care team and system-related factors. The same organization also classifies therapeutic non-adherence as intentional (when the patient does not comply with the treatment, despite knowing it) or unintentional (when the patient does not understand the information provided by the health professional, when the patient forgets to take the medication, or has difficulty in managing the treatment; WHO, 2003).

\section{Socio-Economic and Cultural Factors}

Studies S1 and S8 show that there is no statistically significant association between age and adherence to immunosuppressive therapy. On the contrary, studies S2, S3, S6, S7 and S10 report that, as age increases, patients tend to adhere more to the immunosuppressive therapy. In $\$ 2$, patients in the 46-64 age group show a higher level of adherence, in comparison to younger patients (aged 18-29 years). S3 and S6 reveal that the level of non-adherence is lower in younger transplant recipients, since they are more likely to be occupationally and socially active, having to face bigger challenges.
Studies S1, S2, S7 and S10 indicate that gender and adherence to immunosuppressive therapy are not related. On the other hand, S3 and S6 report a statistically significant correlation between gender and adherence, in which male patients tend to be more non-adherent than female patients. $\$ 6$ shows a positive association between the female gender and the occupational situation, with homemakers reporting a higher level of adherence due to their greater availability.

Studies S2, S7 and S10 show that there is no association between education and adherence to immunosuppressive therapy. In contrast, studies $\mathrm{S}$, S3 and S8 report a statistically significant association between education and adherence, being that patients with a lower level education are less adherent to treatment. However, according to $\mathrm{S1}$, patients with a lower level of education are more interested in acquiring knowledge about the treatment.

Study S8 reports an association between monthly income and adherence to immunosuppressive therapy, being that the lower the income, the lower the level of adherence. Depending on each country's health system and medication costs, patients sometimes choose to skip some daily doses. However, S2 refers that monthly income and adherence are not associated.

Studies S2, S7 and S10 show no association between marital status and adherence to immunosuppressive therapy. However, $\mathrm{S} 3$ indicates that marital status and adherence are related, being that married/co-habiting 
patients have a lower level of adherence. According to the same study, adherence may be undermined by a poor marital satisfaction, or by the relationship itself, since patients, by being involved in household responsibilities, may push aside adherence to treatment.

Studies S2, S7, and S10 report that profession/ occupational situation and adherence to immunosuppressive therapy are not related. However, S3 states that patients in an active occupational situation show a lower level of adherence. $\$ 6$ reports adherence in some occupational situations, as are the cases of full-time homemakers and unemployed individuals, since these patients are more available (are at home and have no other type of occupation). Studies S8 and S10 refer that social support and adherence to immunosuppressive therapy are not related. On the other hand, $\$ 4$ states that there is a positive association between adherence and social support, being that transplant recipients with better social support are most likely to adhere to immunosuppressive therapy. This is corroborated by Cabral and Silva (2010) and Dias et al. (2011), who state that the support received by transplant recipients from their social networks to comply with the treatment can influence their behavior. In turn, transplant recipients who live alone or have a limited social network are more likely to experience difficulties in following the recommended indications. In view of the above, we found that there is some controversy regarding the association between adherence and socio-economic and cultural factors. This is emphasized by the WHO (2003) which argues that age, sex, education, occupation, income, marital status, race, religion, ethnic background and urban versus rural living are factors that have not been clearly associated with therapeutic adherence.

\section{Condition/Comorbidities-Related Factors}

Studies S1 and S7 report that type of donor and adherence to immunosuppressive therapy are not related. On the contrary, S6 refers that there is an association in the case of living donors, in which the level of adherence is higher.

Study S10 refers that time since the transplant and adherence to immunosuppressive therapy are not related. However, S2 and S9 report an association between the time since the transplant and adherence. S6 also confirms this association, while showing that the shorter the time elapsed since the kidney transplant, the higher the level of adherence. In the comparative S7 study, the authors concluded that patients show a high level of adherence (around 83\%) six weeks after the transplant, falling to $73 \%$ six months after the transplant.

As regards depression, S3 considers it to be a factor of non-adherence to immunosuppressive therapy. Therefore, Bugalho and Carneiro (2004) refer that patients with psychiatric disorders have indeed a lower level of adherence, which is related to their social isolation and altered cognitive function. However, studies S8 and S10 found no association between adherence and depression.

\section{Patient-Related Factors}

Studies S2, S3, S5 and S8 report an association between forgetfulness and non-adherence to immunosuppressive therapy. Forgetfulness is often related to changes in the daily routine. In this sense, studies S2, S5 and S8 confirm an association between adherence and daily routines. These studies report that both forgetfulness and the interruption/change of daily routines are the major barriers to therapeutic adherence. Cabral and Silva (2010) refer that forgetfulness is one of the most common behaviors, both in terms of forgetting to take the medication, and not remembering the relevant information about how the treatment should be done.

Study $S 1$ confirms an association between motivation and adherence to immunosuppressive therapy, being that the more motivated the patients are, the higher is the level of adherence. Non-adherent patients have lower levels of satisfaction and less control over their lives, as shown in S2, which reports an association between satisfaction with life and non-adherence to treatment.

Studies S2, S3 and S5 refer that there is an association between beliefs and adherence to immunosuppressive therapy, being that non-adherent patients are more likely to question the need for treatment. In contrast, S7 concludes that there is a statistically significant association between adherence and the beliefs about the treatment.

Study S10 considered self-efficacy to be a factor of adherence. Self-efficacy is a concept associated with self-care. According to the Quality Standards for Nursing Care (Padrões de Qualidade dos Cuidados de Enfermagem), in the "constant demand for 
excellence in professional practice, the nurse maximizes the patients' well-being and complements/ adds to the activities of daily living in which the patient is dependent" (Ordem dos Enfermeiros. Conselho de Enfermagem, 2012, p. 16). Individuals perform self-care activities as an integral part of their lives whenever they act for their own benefit to maintain their health and well-being, and whenever they provide care to their families or community in general.

Study S8 reports that perceived stress, anxiety and literacy have no statistically significant association with non-adherence to immunosuppressive therapy. In what concerns patient-related factors, Cabral and Silva (2010) mention that patients' knowledge about the disease, as well as their personal attitudes and beliefs about treatment effectiveness have been widely recognized as consistent predictors of the level of adherence.

\section{Therapy-Related Factors}

Studies S1, S3, S5 and S6 report an association between the complexity of the treatment regimen and non-adherence to immunosuppressive therapy, i.e., the higher the complexity (frequency of intake and number of medications), the lower the level of adherence. Bugalho and Carneiro (2004), and Dias et al. (2011) confirm this result, mentioning that treatment complexity and duration, frequent changes in medication, the lack of immediate clinical improvement, and the presence of secondary effects can compromise adherence. Additionally, Cabral and Silva (2010) state that the simultaneous prescription of multiple medications, as well as a high frequency of daily doses, or high dosages, can also contribute to a lower level of therapeutic adherence.

\section{Health Care Team and System-Related} Factors

No factors directly related to the health services and professionals emerged from the analysis of the selected studies. However, Bugalho and Carneiro (2004) refer that weak health care systems, the shortage of training on chronic diseases for health professionals, the lack of time for a more effective monitoring (consultations), and the lack of instruments to assess adherence interfere with therapeutic adherence. Cabral and Silva (2010), and Dias et al. (2011) added that the quality of the relationship established between health professionals and patients has a positive effect in the level of adherence, with communication being an essential part of the whole process. In this relationship of trust, two levels of knowledge coexist: lay beliefs and professional beliefs, interacting in a dyad in which communication influences the patient's adherence, expectations, and decisions (Dias et al., 2011).

The above-mentioned analysis shows that the phenomenon of adherence is multifactorial. The most significant factors in this integrative literature review are the socio-economic and cultural factors, the condition/comorbidities-related factors, the patient-related factors, and the therapy-related factors. Taking into account the analyzed factors, and in order to answer the research question, it is essential to identify nursing interventions and strategies to facilitate the adherence process. In Transplant Nursing, therapeutic adherence is a key focus of attention for nurses, requiring constant work, as well as a well-structured, outlined and directed nursing interventions at different levels, aiming at the promotion of adherence and self-care. Based on the analysis of the studies, the authors suggest various strategies for promoting therapeutic adherence: Conducting motivational interviews with a view to promoting and maintaining motivation for medication adherence throughout time; Providing social support. This aspect should be assessed before and after the transplant, particularly regarding the involvement and the emotional and educational support of patients, relatives and friends. The provision of social support, by preparing meals, gardening and/or doing domestic chores, among other activities, although not directly related to adherence, contributes to reducing stress and helps the transplant recipients to relax and focus on their health; Developing a reminder/alarm system, by asking a friend to call regularly (daily, at the same time) or the spouse to organize a daily dose pill box to overcome situations of forgetfulness; Simplifying, whenever possible, the drug regimens of the immunosuppressive therapy; Providing organized daily dose pill boxes and written information about the need and importance of immunosuppressants (guides or leaflets); Electronic monitoring, which is a valid and reliable instrument for managing medications, but it is not easily available and requires additional financial resources; Elaborating behavioral contracts, which are cost-effective and can be done 
in person or by telephone; Providing the contacts of specialized support groups.

Nurses must be permanently vigilant in order to ensure the early identification of any risk factor and situation of non-adherence (Fine et al., 2009). According to the ICN, better adherence is linked to patient safety, leads to better health outcomes, and reduces healthcare costs (ICN, 2009).

According to Bugalho and Carneiro (2004), there are two types of interventions that improve therapeutic adherence: educational and behavioral interventions. Educational interventions allow increasing the knowledge of patients and their families/significant persons about the medication and the disease, by providing verbal, written (leaflets), audiovisual (movies) and/or digital information, through individual or group educational programs. A clear and objective language is essential, taking into consideration the patient's cultural and cognitive level, and the information must be easy to remember. Behavioral interventions help patients to incorporate adaptation mechanisms into their daily routine, facilitate treatment adherence, optimize communication and counselling, simplify the treatment regimens, engage patients in their treatment, provide memos, and encourage or reward improvements in therapeutic adherence (Bugalho \& Carneiro, 2004).

Therefore, nursing consultations can contribute to maximize these interventions. Another alternative is to establish contacts by telephone, regular mail or email. It is essential to explain and understand the indications and side effects of the medication, as well as the ways to overcome them. These are some strategies to promote adherence. It is also important for patients to be informed of their progress and laboratory results (Bugalho \& Carneiro, 2004).

Patients should be actively involved in their treatment, namely by trying to find strategies to prevent them for forgetting to take the medication (using memos, marking the dates of consultations and renewal of medical prescriptions on the calendar; Bugalho \& Carneiro, 2004).

Although there are some recommendations, the current literature still does not allow designing an effective intervention program to promote therapeutic adherence. However, studies show that interventions should address several risk factors, combining educational, behavioral and emotional interventions that must be sustained over time (Bleser Matteson, Dobbels, Russell, \& Geest, 2009; Fine et al., 2009). An ideal intervention program should be able to identify the patient's factors that require intervention, determine the relevance of the strategies based on the patient's cultural sensitivity, and decide when and where the intervention should start (Fine et al., 2009).

\section{Conclusion}

Understanding the behavior of kidney transplant recipients and the factors influencing therapeutic adherence is beneficial to all concerned. Based on the integrative literature review, we found that the main factors contributing to the adherence to immunosuppressive therapy are: socio-economic and cultural factors (age, gender, education, monthly income, marital status, profession/occupational situation, and social support), therapy-related factors (type of donor, time since transplant, and depression), patient-related factors (forgetfulness, daily routines, motivation, satisfaction with life, beliefs, and selfefficacy), and therapy-related factors (complexity of the therapeutic regimen). Although there is no guaranteed method leading to therapeutic adherence, the identification of the factors influencing it allows designing nursing interventions aimed ultimately at promoting the adherence to immunosuppressive therapy. Thus, through the combination of educational and behavioral interventions, nurses should promote adherence and self-care, which will translate into health gains. The need and importance of pre- and post-transplant nursing consultations the teaching-learning process of the kidney transplant recipient was also emphasized.

Although the WHO (2003) reports an association between adherence and health care team/health system-related factors, the studies analyzed in this integrative literature review did not address these factors. For this reason, studies involving these factors should be conducted, in particular regarding the communication between the nurse and the transplant recipient.

The major limitation of this study was the difficulty to equitably compare the 10 studies included, given that the factors influencing the adherence to the immunosuppressive therapy were analyzed from 
different perspectives, using different data collection tools, and different concepts of adherence.

\section{References}

Bleser, L., Matteson, M., Dobbels, F., Russell, C., \& Geest, S. (2009). Interventions to improve medication-adherence after transplantation: A systematic review. Transplant International, 22, 780-797.

Botelho, L., Cunha, C. \& Macedo, M. (2011). O método da revisão integrativa nos estudos organizacionais. Gestão e Sociedade, 5(11), 121-136.

Bugalho, A., \& Carneiro, A. V. (2004). Intervenções para aumentar a adesão terapêutica em patologias crónicas. Lisboa, Portugal: Centro de Estudos de Medicina Baseada na Evidência.

Cabral, M. V., \& Silva, P. A. (2010). A adesão à terapêutica em Portugal: Atitudes e comportamentos da população portuguesa perante as prescrições médicas. Retrieved from https:/www.apifarma.pt/estudos/siteestudos/Documents/ Conclus\%C3\%B5es\%20Ades\%C3\%A30\%20\%C3\%A0\%20 Terap\%C3\%AAutica\%20PT.pdf.

Chisholm-Burns, M. A., Spivey, C. A., \& Wilks, S. E. (2010). Social support and immunosuppressant therapy adherence among adult renal transplant recipients. Clinical Transplantation, $24,312-320$.

Chisholm-Burns, M., Pinsky, B., Parker, G., Johnson, P., Arcona, S., Buzinec, P.,... Cooper, M. (2012). Factors related to immunosuppressant medication adherence in renal transplant recipients. Clinical Transplantation, 26, 706-713.

Dias, A. M., Cunha, M., Santos, A. M. M., Neves, A. P. G., Pinto, A. F. C., Silva, A. S. A., \& Castro, S. A. (2011). Adesão ao regime terapêutico na doença crónica: Revisão da literatura. Millenium, 40, 201-219.
Fine, R. N., Becker, Y., Geest, S., Eisen, H., Ettenger, R., Evans, R., \& Dobbels, F. (2009). Nonadherence consensus conference summary report. American Journal of Transplantation, 9 , 35-41.

Griva, K., Davenport, A., Harrison, M., \& Newman, S. P. (2012). Non-adherence to immunosuppressive medications in kidney transplantation: Intent vs. forgetfulness and clinical markers of medication intake. Annals of Bebavioral Medicine, 44, 85-93.

International Council of Nurses. (2009). Estabelecer parcerias com os individuos e as famílias para promover a adesão ao tratamento: Catálogo da classificação internacional para a prática de enfermagem (CIPE ${ }^{\circledR}$ ). Lisboa, Portugal: Ordem dos Enfermeiros.

International Council of Nurses. (2011). CIPE ${ }^{\circledR}$ Versão 2: Classificação internacional para a prática de enfermagem. Lisboa, Portugal: Ordem dos Enfermeiros.

Ministério da Saúde. Direção-Geral da Saúde. (2012). Tratamento conservador médico da insuficiência renal crónica estádio 5. Lisboa, Portugal: Autor.

Ordem dos Enfermeiros. Conselho de Enfermagem. (2012). Padrões de qualidade dos cuidados de enfermagem: Enquadramento conceptual, enunciados descritivos. Lisboa, Portugal: Author.

Steele, E., Bialocerkowski, A., \& Grimmer, K. (2003). The postural effects of load carriage on young people: A systematic review. BioMed Central, 4(12), 1-7.

Weng, F. L., Chandwani, S., Kurtyka, K. M., Zacker, C., ChisholmBurns, M. A., \& Demissie, K. (2013). Prevalence and correlates of medication non-adherence among kidney transplant recipients more than 6 months post-transplant: A cross-sectional study. BMC Nephrology, 14(261).

World Health Organization. (2003). Adherence to long-term therapies: Evidence for action. Geneva, Switzerland: Author. 

